\title{
Building Helplines and Caring for Missing Children: A Community Project
}

\author{
Subhash Chandra Mamidi*, Bharath Bhushan Mamidi \\ Centre for Action Research and People's Development, India \\ *Corresponding Author: msubhaashchandra@gmail.com
}

\begin{abstract}
Every 30 seconds, a child goes missing in India and majority of them are girls and from poor socio-economic background (Singh, K.P, 2014). Referring to government figures accepting that only 55 percent of them are fortunate to reach their homes, the Supreme Court observed that "Nobody seems to care about missing children. This is the irony," (TNN, 2014). Many of these missing children tragically find themselves being trafficked to an unknown and dangerous world which is sometimes thousands of miles away from home and end up as child labour, begging, inmates of a shelter home, or forced into sex trade. It is possible to ensure child protection and address the problem of missing children with active support of the civil society and fortunately there is growing involvement of the NGOs. The present paper described the processes utilised by a team of volunteers with limited resources that successfully assisted 370 missing children reunite with their families. The paper while presenting the broad learnings in this field suggests practical measures that are replicable, prominent amongst these is the role of civil societies, volunteers, media and ICT.
\end{abstract}

Keywords Missing Children, Child Protection, Community Empowerment, Resilience, Hope, Civil Society

\section{Introduction}

A missing child is a parent's worst nightmare and a big challenge to the state to prevent and trace a missing child in a country of 1.25 billion people having diverse cultures and 1635 mother tongues according to 2011 Census or 780 languages (IANS, 2013), spread across 3,287,590 Sq.Km. India has the world's largest child population of above 400 million and is part of UNCRC for the child's protection and development. Data onmissing children put out by the Home Ministry in July 2014 in Parliament show that over 325,000 children went missing between 2011 and June 2014, at an average of above 100,000 children missing every year
(Bhalla, J.S. 2014). What is more disturbing is that "at present Missing Children remains a neglected, low priority intervention area for everyone other than those who have lost their children" (NHRC, 2007, p. 3) and that "around 170 million or 40 per cent of India's children are vulnerable to or experiencing difficult circumstances." (NCPCR, 2013 p. 65). According to government data, in India, during the period from 2009 to2011 number of children that have gone missing are 2,36,014 and out of them 75,808 are still untraced. However, only 34,899 First Information Reports (FIRs) have been registered in all. Missing cases are not considered worthy of serious investigation by the police department. The number of missing children would be much higher as most of thecases are not reported (Childline India). Approximately a million children go missing every year in India and percentage of children returning home would be much less than 55 per cent according to estimates of NGO.

The common variable is poverty both for rural and urban with worryingly, 55 percent of those missing appear to be girls (TNN, 2014). More than 40 children go missing every day in the capital of India (Delhi) and a minimum of 3 children go missing from India Gate every day, the place which is considered to be one of the most secured places in terms of police vigilance (Singh, K.P., 2014).

The problem of missing children is quite alarming in Telangana and Andhra Pradesh states ${ }^{1}$. According to Central Investigation Department (CID), there was an alarming rise in the number of missing persons including women and children during the last four years in Andhra Pradesh and a total of 17,030 children were found missing since 2009 and police could trace only 302 children till August 2012 (Press Trust of India, 2012). Tracing a missing child is a highly arduous process and may take long time because there is no national level monitoring agency to coordinate with the state machinery engaged in tracing missing persons. A local girl was traced in Gujarat state after eleven agonising years.

\footnotetext{
${ }^{1}$ These are two new states carved out of the former Andhra Pradesh in June 2014. Any reference to Andhra Pradesh state in this paper includes data about Telangana.
} 
State protection for missing children has been very poor or nil because of gross indifference and ignorance of the issues. Serial killings, sexual abuse and rape of children in Nithari village, situated about $20 \mathrm{kms}$ from Parliament House in Delhi, in 2006 shocked the country to utter lack of any mechanisms to trace missing children in India. Nithari incidents, the Ministry of Women and Child Development (MWCD) report observed, "reflect the general national apathy and malaise in the administrative system, especially the police in tackling the problems of children and ensuring their safety and protection-one reason for the growing incidence of crimes against children. This is more so in the case of poor and downtrodden whose voice is not heard" (MWCD, 2007 para. 4.4). Government of India also acknowledged "the growing incidence of child abuse, violence and trafficking and kidnapping of young children for various purposes ranging from prostitution, rape, ransom, sale of organs, child labour, servitude etc" and stressed "urgent need to put in place measures for a safe protective environment, which will provide our children the safety and protection they need to grow into productive and happy individuals" (MWCD, 2007).

\section{Where Does a Missing Child Go?}

There are patterns observed about locations where many children go missing. Children are seen in platforms and bus terminals characterized by huge crowds. While some children are lost others are kidnapped andtrafficked by organised gangs. A missing child is also likely to be trafficked before reaching the authorities or a civil society organization for support. Anecdotal reports suggest that missing children end up in the following places:

- Shelter home run by NGOs: These children are comparatively lucky. They are provided shelter because of the financial support by the donors and information is not shared with any government department.

- Some of the missing children are forced into begging: Around 60,000 children are forced to work as beggars in India by organized, mafia-like criminal groups (Harikrishnan, K.S., 2014).

- Kidnapped for ransom: "Figures from Delhi police show that kidnap for ransom is on the rise. In 2008, there were 1,233 cases in the national capital; in 2010 that had soared to 2,975 . In the first three months of 2011, 802 cases were registered," (Chamberlain, 2011).

- $\quad$ Child labour and domestic help: Two decades after a nation wide ban on child labour in hazardous industries was introduced. There were 4353247 children, aged between 5 and 14, engaged in dangerous occupations according to Census 2011 (Ministry of Labour and Employment).
- Sex work and organ trade: Child trafficking is a \$360 billion sex trade in India every year which is about one-fifth of the country's gross Domestic Product, according to Kailash Satyarthi, the recipient of Nobel Prize for 2014 (Masoodi, 2014). India is considered the hub of human trafficking for sexual exploitation and bonded labour in Asia. These missing children land up in Begging Rings, Prostitution, Pedophilic Net and Organ Trade or end up getting exported for Camel Jockeying etc. (MHA, 2012).

\section{State Interventions-A Beginning is Made}

There have been several measures initiated by government of India, being a signatory to the UN Convention for the Rights of the Child, in the areas of education and health. These efforts with regard to basic rights of safety, survival and protection of children have just begun in India. The National Human Rights Commission (NHRC) observed that "missing children is a veritable black hole in law enforcement. The police and State/ UT govt. including local administration until now have failed to even acknowledge the problem" (NHRC, 2007 p. 21). Neglect of the problem is reflected in abysmally low budget allocated for child protection. Child budgeting by the MWCD revealed that total expenditure on children (health, education, development and protection) was 3.86 per cent in 2005-2006 and 4.91 per cent in 2006-07 while the share of child protection in the Child Budget remained a mere 0.03 per cent from 2004-05 to 2006-07. Problem of missing children seems to be entirely out of the current agenda of policy and law. It is only recently the definition of 'missing child' in India has been written (May 2013) with the Supreme Court of the country coming to the rescue: "a person below eighteen years of age, whose whereabouts are not known to the parents, legal guardians and any other person, who may be legally entrusted with the custody of the child, whatever may be the circumstances/ causes of disappearance. The child will be considered missing and in need of care and protection within the meaning of the later part of the Juvenile Act, until located and/or his/her safety/well being is established"(Bachpan Bachao Andolan, 2013).

Growing attention to the problem during past seven years also witnessed the important initiatives that include 'Integrated Child Protection Scheme (ICPS)' in 2009, 'Comprehensive Scheme for Prevention of Trafficking of Women and Children and their Rescue and Rehabilitation' in 2007, National Commission for Protection of Child Rights in 2007, setting up of Childline and women helplines, 'TrackChild' for database on missing children. The ICPS introduced by the MWCD aims atcontributing to the improvement in the wellbeing of children in difficult circumstances, as well as to the reduction of vulnerabilities 
to situations and actions that lead to abuse, neglect, exploitation, abandonment and separation of children. The ICPS also introduced a mechanism for tracking 'missing' and 'found' children under ICPS and Juvenile Justice (Care and Protection of Children) Act, 2000. TrackChild, a national portal initiated in 2012, provides an integrated virtual space for all stakeholders and ICPS bodies in the 35 States and Union Territories and helps in tracing and reviewing the progress of efforts reuniting missing children with their families. However, the effectiveness of TrackChild is dependent on seriousness of police and "strong orders for recording all cases of missing children at the police stations are needed for the success of the program" (MWCD, 2012).

Considerable progress has been made in developing database, collecting and dissemination of information about missing children in India. However, there is still long way to go to make this data put to optimum use and analysis. For instance, the TALAASH (search) Information System maintained by NCRB (http://ncrb.gov.in ), a national level database of missing persons under the broad categories - 'missing', 'kidnapped', 'arrested', 'deserted', 'escaped', 'proclaimed offender', 'wanted', 'unidentified dead body', 'unidentified person' and 'traced/found' did not provide data on missing children under the category of 'missing' until recently. Although "the category of missing children hascome to be reflected in the TALAASH Information System, there is no mention or analysis of it to date in the Crime in India Report published by the NCRB" (NHRC, 2007). The Childline, operating from over 282 locations across India in partnership with 543 partners also supplements the efforts in tracing missing children. The Childline "has so far received 38,22,081 complaints of which 4 per cent are about missing children" (Bhalla, 2014). Childline India Foundation's 24-hour toll free, emergency phone service is for children in distress and long-term care and rehabilitation of children in need of care and protection i.e., the street children, child laborers, child victims of flesh trade, differently abled children, child addicts, missing children, domestic workers and sexually abused children, etc.

\section{NGO's Role}

The NHRC Report 2007 observed that several nongovernmental organizations have been doing commendable work in this field. However, funding has been a serious issue with non-governmental organizations (NHRC, 2007 p. $20-$ 21). NGOs played key role in not only addressing the problem of missing children but also developing different approaches that aid in protection of the missing children through locating missing children (Bal Sakha, Patna, www.balsakhaindia.org), information portal through a website that provides details of missing children collected from parents and police stations (National Centre for Missing Children, Madhya Pradesh www.missingindiankids.com), $24 \times 7$ toll-free tele-helpline for children in distress to seek help (Childline, www.childlineindia.org.in) among other methods to tackle the problem. Experiences of NGOs have provided empirical basis to evolve different strategies to answer the problem. UNICEF collaborated with the MWCD in the creation of a website for Missing Children to facilitate tracing and reintegration of lost children. In this paper a case study of an NGO called Centre for Action Research and People's Development (www.carped.org) is presented.

Centre for Action Research and People's Development (CARPED), established in 1989, is a not to profit registered society engaged in promotion of child rights, participatory forest management, women's sexual and reproductive rights, mother and child health, environment education, sustainable livelihoods and tribal development through pilot programmes to help improve programme design and advocacy for people's agenda. Community mobilization interventions in varied sectors are focused in Telangana and Andhra Pradesh.

CARPED as part of its commitment to children undertook the helpline approach through an coordinated approach with other NGOs and shelter homes. The aims were to trace the parents or children and to primarily to reunite the missing child with one's family.

CARPED discovered that most of the children are not able to provide complete address of their residence and cannot communicate due to language barriers when they land up in places far from their own. Staff also have not been trained to elicit through some clues to establish the geography of the state from where these children have emerged. This makes the task of tracing their parents and restored to the families a difficult task.

Certainly, there is no substitute for a home. There are very few agencies providing shelter to missing children. Missing children in search of their parents and family face several hardships and risks. Not all children areable to rejoin their families. Estranged from parents and home, one's childhood is lost, deprived of mother's love and affection, security fromthe family and joy of playing with siblings. These children are deprived of protection and guidance that is critical to the growth of personality and identity. If stayed missing for a long time, the child might even forget one's mother, family and culture.

CARPED started working on the issue from September 8, 2010 with acall from a Delhi based activist to help a child with challenges of speaking and hearing. Nothing much could be done from Hyderabad and had to visit a home in Delhi and found 4 more Telugu speaking children who are unable to remember their address or contact details. The volunteer who visited the place realised the need for a different solution and that is tracing parents. A team of five members started on the journey to Delhi with no resources or experience except commitment tohelp four Telugu speaking missing children. That incident made the team realise the need for attention to the problem of missing children. The 
team grew over the years with more volunteers joining. In four years they could rescue 370 missing children and address myriad forms of vulnerabilities and risks apart from reuniting with their families.

The experiences helped evolve strategies that are effective and result oriented within the constraints of financial resources and team size. Over the years the experiences from the work in different parts of the country helped build a network with stakeholders across the country- NGOs, shelter homes, officials from Police and Labour department, students as volunteers and media. Networking with like minded individuals and NGOs, officials, use of social media, mobile phones, desk research, field visit for investigation, documentation, convergence with government departments, training on procedures to volunteers, conducting rescue operations and raids formed some of the important tools and strategies in the mission. Focus was on tracing the parents based on information provided by the missing kid or tracing the child based on information given by the parents. Much of the success lies in connecting the dots and examining every little source of information to rebuild a broken bond towards restoring child's right to live, right to an environment in which they can grow up healthy and safe.

\section{Methodology of CARPED Helpline for Missing Children}

- Desk research and contacts in the said locations to identify the concerned schools, Sarpanches (elected heads of the villages in the Indian democracy), Local police officials, Child Welfare Committees and local news reporters to verify the incidence of missing children. Use of internet is very helpful to identify the places and stakeholders.

- Networking and building contacts with NGOs and shelter homes in different parts of the country. "We contact them or they contact us as the situation demands to address the problem of a missing child or parents in search of their child. The interaction becomes the source for future references and investigations", says a volunteer.

- $\quad$ Publicise details of the missing child through media. Volunteers are also alerted to trace the parents/child.

- Use of mobile phones to talk to children for rough clues to reach the parents and keep the volunteers updated.

- $\quad$ Field visits to the locations to meet the child or parents and seek support of local officials and the community. Documentation of the procedures and reporting to the concerned officers.

- On tracing the child/parent, organise a dialogue between child and parents over mobiles is facilitated to confirm the right tracking of the child or parent. Children are produced before the Child Welfare Committee for orders. The committee is a bench of magistrates to deal with the issues related to the welfare of the children.

- ChildLine India Foundation partnered with CARPED to run a toll free child helpline 1098 in Medak district since November 2012.

- $\quad$ Organise informal meetings, seminars in colleges and corporate offices for enlisting volunteers who speak different languages to understand child's information and identify clues about one's family and address. Volunteers in other states pass the information to the team by emails with all details including photos or small videos.

- Enlisting volunteers to create awareness among students and community on the procedures and whom to approach when a child goes missing. Osmania University, S.P. Jain Institute of Management and Research, Law College -Vishakapatnam, etc were part of organizing sensitization programmes.

\section{CARPED Experiences in Tracing Missing Children}

"Kahte hai dhoondne se toh khudaa bi milta hai" (through search one can even find God). At least that is the belief which kept us working within the organisation.

Case of a policeman searching for his son is an example of the difficulties involved in tracing a missing child. Parents seek help of police when a child is missing. But the irony was that a police officer's son was missing from Nizamabad district in Telangana since 2011. All his efforts to trace the child have not been fruitful. Boy's father is transferred to another place and the mother continues to reside in the same old house with the hope that her child would return one day, as that's the only thing child remembers of the home. She keeps visiting the police station every week.

Tracing a missing child is very difficult exercise. There are instances where a child is reunited within 2 hours, but a few problems take years. Missing children traced by volunteers of CARPED are from almost every district of Andhra Pradesh and Telangana. These missing children were in places as distant as Mumbai, Bhubaneswar, Delhi, Sholapur, Bangalore, Gulbarga, from places all over the country. CARPED team began responding to information received from NGOs, Police and state agencies including print and television media. Helpline team traced achild of Rangareddy district in Telangana who was spotted in Delhi railway station and the railway police handed him over to a shelter home in Delhi while the child's parents had traumatic months of agonising search (see Annexure 1).

\section{Saidamma - Teenage Girl Rescue}

Narayandas Ramasawami and his wife Ramulamma are residents of Pedda Adisherlapalli of Nalgonda, Telangana. They are very poor and migrated to Guntur in search of employment in Andhra Pradesh. They started working as 
daily wage labourers and returned home to take their 15 year old daughter Saidamma with them. She has a dual diagnosis for intellectual disability and mild mental health and also has speech impairment. They were travelling to Guntur by train and the father got down at a Macharla Railway station to buy food and train left with the girl. Four months passed and there was no information about the girl. Parents were worried as it was not safe for girls. More dangerous for Saidamma as she is a grown up girl. With her state of incoherence, impaired speech she was unable to give her parental address. This girl was never to be traced unless for a chance event that occurred in following months. A Hyderabad based Sociology student and a volunteer of CARPED was on a exposure visit to Mumbai and also visited shelter home run by the Government and has come to know about the child. She was surprised to a see a Telugu speaking girl in Mumbai, about $800 \mathrm{Kms}$ away from her home, without any details of her home except name of the village. She passed on the information to the team which enquired with volunteers from Nalgonda. The volunteers visited the village and found parents of the missing girl.

There are many such similar cases, an Orissa based NGO contacted CARPED to help a lost girl reach her home in Andhra Pradesh. Only information available was names of her parents (Edaswami and Terpama) and village name (Mustukunta and Chetampeta). Hopeline team tried all combinations and permutations and zeroed in on thevillages as Mushtikunta (Bonakkal Mandal) and Seetampet (Chintakani Mandal) of Khammam district. With the help of a local sub-inspector, CARPED found out that she is a 14 year old girl from Thimminenipalem under the jurisdiction of Chintakani Police station. A girl with mild to moderate intellectual disabilities and therefore with special needs. Her parents are nomadic and traditionally beggars who go out before sunrise and seek alms playing the drums before the villagers. Owing to their poverty, they did not even have a photograph of the girl, hence were unable to make a formal police complaint for nearly 9 months. The child returned home due to the efforts of a Sub Inspector who moved from his station duties to yet another station on transfer. He provided information about the Hopeline team to the new officer- in- charge before he moved to a new place. The police then began to ring Hopeline team whenever they receive information of a missing child.

Some barriers are overcome through networking among the NGOs, even across borders. Some of the missing children traced by Hopeline team were trafficked from Nepal. Esther Benjamin Trust-a Nepal based NGO (www.ebtrust.org.uk) contacted CARPED with information of Nepal children working for a circus company in Andhra Pradesh (TNN, 2010). Nepal NGO knew of middlemen trafficking children to India, but required support of a local civil society organisation to track and rescue the children in a foreign country. The affected parents and children were totally helpless. Clues of the Nepal NGO helped CARPED team to investigate the circus companies in Andhra Pradesh and was suspicious of Great Prabhat Circus which was earlier booked for employing children.

CARPED team conducted a raid on the Circus Company in Chittoor district with the help of Police and Labour departments and rescued 27 children - 9 Nepali children and 18 children of Guntur and Prakasam districts of Andhra Pradesh (TNN, 2010). Except one boy, all were girls aged 9 to 14 years. The rescued children complained of harsh living conditions. They were denied food and sleep as they had to practice of dangerous feats for long hours every day. A few of them also had bruises. The circus company was booked under the Child Labour Act for discreetly trafficking children from across the border and exposing them to inhuman working conditions. Nepali children were sent back to their country with help of the NGO, other rescued children are kept at shelter homes in Chittoor till their family members contact them through the nearest police station (see: Annexure 2).

Some of the missing children spend long time in the shelter homes because of many factors- procedural requirements, budgetary limitations, language barriers, lack of motivation among the staff, etc. Most cases of missing children require a proactive approach and concern that is vital for resulted oriented interventions. Care and concern prove to be most powerful means in addressing the problem of missing child where institutional mechanisms are not effective at times. Student interns with Hopeline and volunteering for a cause were on avisit to Mumbai and also visited a shelter home run by the government. There they met a girl who also speaks Telugu. "I am an illiterate and cannot speak Marathi or Hindi. I do not know how to explain and whoto report. I could not provide any information to the people here. Can you please help me reach my home," she told the volunteers.

Ananthamma, a 15 year old Kannada girl of Vadavati village from Raichur district of Karnataka state was travelling with her maternal uncle, who left her at Basvanabai bus stand and went for purchasing snacks and later she realised she was in a new place, she said."I am still trying to remember and I don't know how I came here", she told. She is fortunate that she reached a shelter home and nobody knows who brought her from bus stand to Mumbai. Parents (Thimmappa and Hussainamma) were traced. Parents told that her uncle was shocked and helpless when the girl disappeared by the moment he returned with snacks. "We tried our best and thought she must have been kidnapped but there was no demand for ransom. We were worried that she must have been trafficked or killed", they told.

\section{Conclusions}

Tracing missing children is a serious problem in India for the sheer number of children that go missing every day and for the harm they suffer for no fault of theirs in this rather mean world. Missing children or trafficking violates all 
rights a child is entitled to. Interventions to address problem of missing children need to focus on how early a missing child is rehabilitated and protected from the dangers of being separated from one's parents and home. Missing children in search of their parents and family face several hardships and risks. Estranged from parents and home, one's childhood is lost, these children are deprived of protection and guidance that is critical to the growth of personality and identity. Policy measures need to ensure space for creativity and flexibility. Community sensitisation and engagement of civil society requires more improvements and convergence and partnership with civil society andthe state is paramount. Application of ICT and traditional means of communications need to be improved to ensure effective participation of the stakeholders and build a large network of concerned citizens to prevent violation of child rights in the country. Experiences of NGOs across the country provide testimony of their role in addressing the problem of missing children. Certainly urgent measures are required to launch large scale awareness among all sections of the society so that an alert and concerned force is in place to ensure safety for children in the country.

\section{Annexure}

\section{Annexure1}

\section{A Telugu boy of Rangareddy District Traced in Delhi Shelter Home-Months of Trauma Ends}

It was dark and their son, Venkatesh, is not at home, $\mathrm{Mr}$ Vadde Venkatayya and Mrs Shanthamma realised that their 12 year old son didnot return home and searched for him in the village of Basheerabad of Ranga Reddy district, situated in the borders of Telangana and Karnataka states. Worried parents went to all the places the child frequents and playground. Next day they enquired with all his friends and visited all the relatives where his son goes regularly. They are poor daily wage labourers and have spent all that they had and also taken loans from every known person. Nobody was willing to lend them anymore as they were not able to attend to any work and repay the loans. After 2 months, they filed a complaint with Police on September 28, 2010 (FIR No.61/2010 dated 28-9-2010 under section 154 and 157 Cr.P.C.) and Police notified this through local editions of Telugu newspapers.

CARPED's Hopeline team came to know about the missing child and enquired with all the shelter homes. Parents don't have a photograph or any other identity of the child. The Hopeline team found that before the boy went missing, he asked for Rs 100 and his parents denied. There is a railway line very close to his house and the team learnt that the boy was also called Ravi.

Team enquired with all the known shelter homes with all the names he is called with and found him in Delhi which is $1600 \mathrm{Kms}$ away from his home. After talking to the child over phone, he said that he travelled for 2 days without food and he was lucky to get caught by the police on July 172010 and was sent to a shelter home in Delhi. The team had telephonic conversations with the child and social workers in the home, exchanged mails and received photo of the child. The team visited the village for enquiry and showed the photograph to the Police who have confirmed the details and called the parents to the police station.

There was no end to the joy of the parents when they saw photograph of their son. They confirmed the identity of the child missing for 2 months. Parents took the Hopeline team to their house and told about sleepless nights and how every minute they remember the child.

"My child is alive in New Delhi. I was getting worried when news spread of a child sacrifice in the nearby village just a week ago", told the mother with moist eyes. "Will cook good food today and raise loan from neighbours to visit Delhi soon to bring back our son", she told.

The Hopeline team met Sarpanch (village head), verified landmarks and names of his parents and maternal uncle with the clues given by the child. The team also collected FIR, Look out Notice, ration card of the family and other evidence of the enquiry and process of restoration. While enquiring about Ravi in Delhi shelter home, the Hopeline team also found details of four more missing children of Andhra Pradesh living in different shelter homes in Delhi.

\section{Annexure 2}

\section{Children Rescued from a Circus Company}

HYDERABAD: Twenty seven children, including nine Nepali nationals were rescued at Chittoor from a circus company. All aged between nine and 14 years, the circus company, Great Prabhat Circus, has been booked under the Child Labour Act for discreetly trafficking children from across the border and exposing them to inhuman working conditions. Significantly, except for one boy, all the rescued children were girls.

The joint rescue operation which was carried out on November 25 by Chittoor police, labour department and Centre for Action Research and People's Development (CARPED) was based on a tip-off from a Nepal based NGO, Esther Benjamin Trust.

Officials involved in the rescue operation said that the children from Nepal were picked up from their respective houses when their parents were busy working in the agricultural fields. They were later trafficked by middlemen to India. According to rescue team members, parents of the trafficked children in Nepal were given Rs 500 each month, though that money failed to reach them on time.

The other rescued children were from Guntur and Prakasam districts of Andhra Pradesh. Apart from Nepal, Bangladesh is another country from where children are known to be frequently trafficked to the state by similar 
circus companies, officials said. Great Prabhat Circus had in the past too come under the scanner for employing children in its company.

"They were exposed to harsh living conditions. They were not only denied food but were also not allowed to sleep properly," said M Subhash Chandra, director, CARPED.

While the Nepali children will be sent back to their country with the help of the Esther Benjamin Trust, the other rescued children will be kept at shelter homes in Chittoor till their family members contact them through the nearest police station.

Source: TNN. 27 children rescued from circus company, Times of India, Nov 30, 2010, Hyderabad.

\section{REFERENCES}

Bachpan Bachao Andolan (2013). Supreme Court delivers a landmark judgement on missing children. [ONLINE] Available at: http://www.bba.

org.in/?q=content/supreme-court-india-delivers-landmark-judgeme ntmissing-children. [Last Accessed 12 October 2014].

Bhalla, J.S. (2014). Govt to integrate childline with missing kids' portal. [ONLINE] Available at:

http://www.dailypioneer.com/nation/govt-to-integrate-childlinewit h-missing-kids-portal.html [Last Accessed 12 October 2014].

Chamberlain, G. (2011). Heartache for India's new rich as brutal kidnappers target their children. [ONLINE] Available at: http://www.theguardian.

com/world/2011/jul/10/india-howrah-kolkata-kidnap [Last

Accessed 12 October 2014].

Harikrishnan, K.S. (2014). Child Trafficking Rampant in Underdeveloped Indian Villages. ONLINE] Available at: http://www.ipsnews.net/2014/

09/child-trafficking-rampant-in-underdeveloped-indian-villages/ [Last Accessed 12 October 2014].

IANS (2013). 780 languages spoken in India, 250 died out in last 50 years. [ONLINE] Available at:

http://www.hindustantimes.com/lifestyle/books/780languages-spo ken-in-india-250-died-out-in-last-50-years/article1-1093758.aspx [Last Accessed 12 October 2014].

Manral, K. (2013). Where are our missing children? [ONLINE] Available at:

(http://blog.tehelka.com/where-are-our-missing-children/ [Last Accessed 12 October 2014].

Masoodi,A. (2014). The human cost of sex trafficking. [ONLINE] Available at: http://www.livemint.com/Politics/NF6no9 ZE11TQWyV2CLF8LI/Thehuman-cost-of-sex-trafficking.html [Last Accessed 12 October 2014].
MHA (2012). Office Memorandum- Subject: Advisory on missing children- measures needed to prevent trafficking and trace the children- regarding, 31st January 2012, Ministry of Home Affairs, New Delhi. [ONLINE] Available at:

http://stophumantrafficking-mha.nic.in/writereaddata/CS-AdvMis gChd070312.pdf [Last Accessed 12 October 2014].

Ministry of Labour and Employment (2014). Child labour census 2001 and 2011. [ONLINE] Available at:

http://labour.gov.in/upload/uploadfiles/

files/Divisions/childlabour/Census-2001\%262011.pdf [Last

Accessed 12 October 2014].

MWCD. Integrated Child Protection Scheme (ICPS) - A Centrally Sponsored Scheme of Government - Civil Society Partnership. Ministry of Women and Child Development, Government of India, New Delhi. [ONLINE] Available at:

http://wcd.nic.in/schemes/icps.pdf [Last Accessed 12 October 2014].

MWCD (2007). Report of the Committee Investigating into allegations of large scale sexual abuse, rape and murder of children in Nithari village of NOIDA (UP), Ministry of Women and Child Development, Government of India, January 17, 2007, New Delhi. [ONLINE] Available at: http://www.wcd.nic.in/nitharireport.pdf [Last Accessed 12 October 2014].

MWCD (2012). Minutes of the Third Regional Consultation for cross learning on ICPS between states, held on $17^{\text {th }}$ December, 2012,Ministry of Women and Child Development, Government of India, New Delhi. [ONLINE] Available at: http://wcd.nic.in/icpsmon/pdf/Regional\%20consultation/Minutes 201213 Thirdregionalconsultation.pdf [Last Accessed 12 October 2014].

NCPCR (2013). Status of Children in 14-18 Years: Review of Policy, Programme and Legislative Framework 2012-2013. National Commission for Protection of Child Rights, New Delhi. [ONLINE] Available at: http://ncpcr.gov.in/view file.php?fid=466. [Last Accessed 12 October 2014].

Penna, S.K. (2010). Messiahs Embark On Tracing The Missing Six Children Restored To Parents, Jagran-City Plus, November 19, 2010, Hyderabad.

Press Trust of India (2012). Alarming rise in number of missing people in Andhra Pradesh. [ONLINE] Available at: http://timesofindia.indiatimes.com/india/

Alarming-rise-in-number-of-missing-people-in-Andhra-Pradesh/ar ticle show/15888175.cms. [Last Accessed 12 October 2014].

Singh, K.P, (2014). Kids go missing from India Gate every day. [ONLINE] Available at:

http://www.hindustantimes.com/india-news/three-kids-gomissingfrom-india-gate-everyday -say -police/article1-1272865.aspx. [Last Accessed 12 October 2014].

TNN (2010). 27 children rescued from circus company [ONLINE] Available at:

http://timesofindia.indiatimes.com/city/hyderabad/27-children-resc ued-fromcircus-company/articleshow/7012553.cms.[Last Accessed 12 October 2014]. 